\title{
El Médano rock art style: Izcuña paintings and the marine hunter-gatherers of the Atacama Desert
}

Benjamín Ballester*

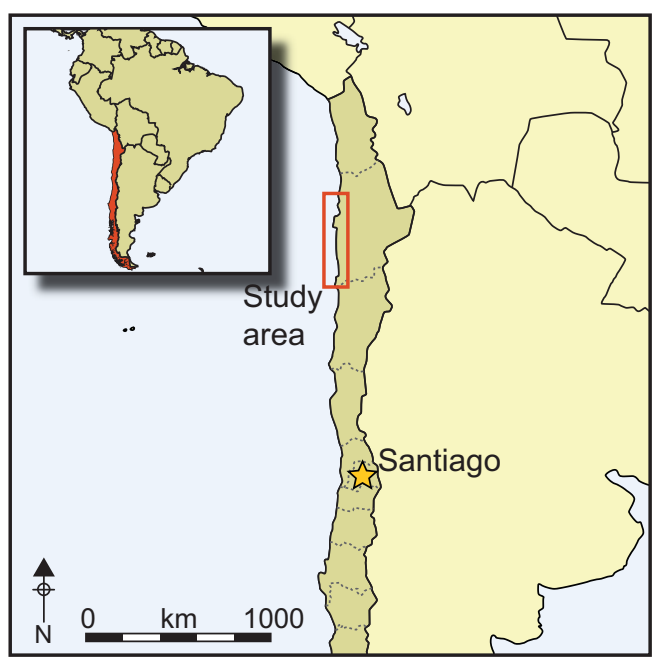

Keywords: Chile, Atacama Desert, Izcuña ravine, pre-Hispanic, marine hunting, pictographs

\section{Introduction}

Few places in the world display such a restricted focus of rock art subject matter as is seen at El Médano, located on the Atacama Desert coast in northern Chile, with its emphasis on marine hunting (e.g. McCarthy 1961; Dikov 1971; Turner 1973; Lundy 1974; Hudson \& Conti 1981; Burningham 1994; Conti et al. 1999; Meighan 2000; Lee \& Robineau 2004; O'Connor 2008; Bland 2010; Torres et al. 2011; Specht 2012; Jeon \& Kim 2013). The pre-Hispanic inhabitants of this littoral used lineal strokes of intense red colour to create naturalistic images of whales, swordfish (Xiphias gladius), marlin (Makaira indica), squid, sea lions, turtles and sharks; some are hunting scenes, featuring rafts with seafarers

* UMR7041 ArScAN-Équipe Ethnologie Préhistorique-Université Paris 1 Panthéon-Sorbonne, 21 allée de l'université, F92023 Nanterre cedex, France (Email: benjaminballesterr@gmail.com) 
and harpoon lines (Figure 1) (Mostny \& Niemeyer 1983, 1984; Núñez \& Contreras 2003, 2008; Berenguer 2009; Niemeyer 2010; Gallardo et al. 2012; Ballester \& Gallardo 2016).

This figurative and pictorial ideology
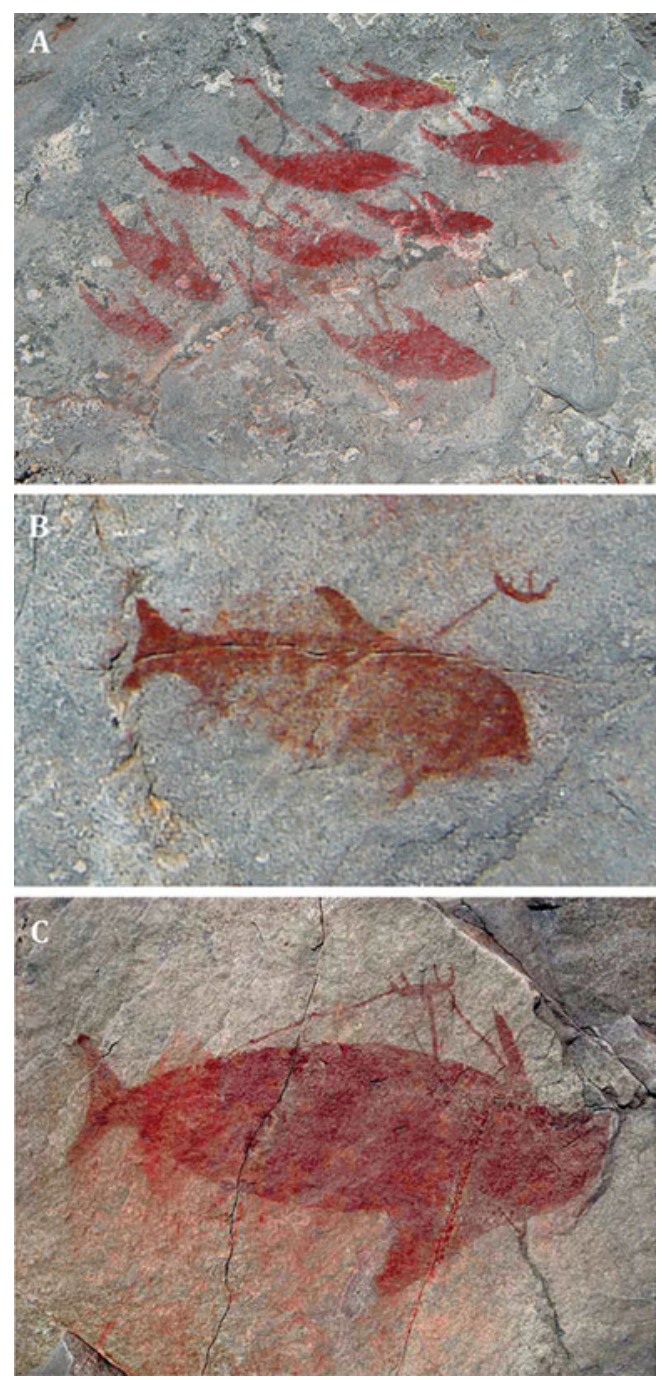

Figure 1. Hunting scenes from El Médano ravine (photography by Francisco Gallardo). was founded on the everyday experiences of these inhabitants, and it is quite probable that their economic, political and symbolic values were strongly influenced by their marine hunting activities (Ballester et al. 2015). Archaeological evidence attests to a society specialised in marine resource exploitation. Its sophisticated fishing and hunting technology included fish-hooks made from shell, bone, cactus spines and copper, and cotton lines, nets, stone weights, harpoons and rafts made of sea lion skin (Mostny 1964; True 1975; Llagostera 1989, 1992; Núñez 1999; Castelleti 2007; Ballester \& Clarot 2014; Salazar et al. 2015). This specialisation and the resource-rich Pacific coast allowed the inhabitants to be hugely productive, thereby facilitating permanent residential camps located near water springs and on natural jetties. From here, small groups could explore vast territories (Ballester \& Gallardo 2011).

Pictographs can show aspects usually difficult or impossible to derive from archaeological materials. While bone assemblages from residential middens demonstrate the capture, butchering and consumption of large marine species, such as swordfish, marlin, tuna (Thunus sp.), dolphins (Delphinidae), sharks (e.g. Notorynchus cepedianus, Galeorhinus galeus, Isurus oxyrinchus), and some cetaceans (e.g. Phocoena spinipinnis), their social, symbolic and cultural role continues to be underestimated (Mostny 1942; Bird 1943; Núñez et al. 1974; Contreras et al. 2011; Castro et al. 2012; Olguín et al. 2014, 2015; Rebolledo et al. 2015; Béarez et al. 2016). Maritime representations in rock art depict aspects such as hunting strategies (e.g. the artefacts involved and prey selectivity), performances, gestures, movements, labour cooperation and hunting roles. They also convey a complex understanding of the anatomical, physiological and behavioural aspects of the animals 
depicted. This article presents newly discovered rock art at the Izcuña ravine and considers its place in the economy of the pre-Hispanic inhabitants of the Atacama Desert coast.

\section{Environment, location and landscape}

The Atacama Desert coast is the natural boundary between the world's most arid desert and one of its richest oceans. The ocean was, and continues to be, the biggest resource provider for the region and an excellent environment for facilitating littoral human habitation. The coastline is irregular, composed of a longitudinal chain of sand bays, pronounced peninsulas and rocky points, thus creating a complex and diverse environment. From the earliest settlers to the present day, the protected bays have been the preferred locations for settlement. As the Loa River is the region's only estuarine river, more than $550 \mathrm{~km}$ of coastline lacks a rich estuarine ecosystem. Here, human settlements have focused principally around natural springs (Núnez \& Varela 1967-1968; True 1975; Llagostera 1979, 1989). A plain comprised of ancient marine terraces, and measuring a maximum of $2 \mathrm{~km}$ across, rises gently from the coast until it meets an imposing cliff line-the foothills of a coastal mountain range that reaches $3000 \mathrm{~m}$ asl (Paskoff 1978-1979).

Irregular, large-scale alluvial inundations caused by intense and heavy rains have formed hundreds of ravines and gullies that descend from the coastal mountain range to the littoral terrace. Natural springs in the dry watercourses and the dense fog (or camanchaca) that enters ravines from the coast allow for the formation of a unique and rich vegetal and faunal ecosystem.

One of these ravines is Izcuna, located $47 \mathrm{~km}$ north of Paposo and $115 \mathrm{~km}$ south of Antofagasta (Figure 2). The ravine measures $14 \mathrm{~km}$ in length, and descends from approximately $1700 \mathrm{~m}$ asl to the coastal plain. It is morphologically steep, characterised by a $\mathrm{V}$ section, and comprises hundreds of curves and deviations. Two large springs are present near the mouth of the ravine, with associated important flora and faunal species. The enormous value of the ravine to the coastal people is evidenced by a remarkable concentration of pre-Hispanic and Hispanic archaeological remains.

\section{El Médano rock art history}

In April 1918, Augusto Capdeville, a customs official and expert in Taltal archaeology, recorded a set of painted rocks in El Médano ravine, located five miles north from Paposo, a small fishing town on the Atacama Desert coast. Along with a detailed map of the site, he briefly recounts the presence of fishing nets, rafts, "llamas or guanaco herds", in addition to "Indians pointing with arrows to guanacos, some of them kneeling, and others throwing harpoons to big fishes (swordfishes), maybe whales, and others from the boats, picking with lines the fishes" (Capdeville 1918: 73) (Figure 1). The site was rediscovered in 1973; a local mining prospector had long known of its existence and revealed it to a geologist, who immediately notified archaeologist Hans Niemeyer. It was his work that determined the place of El Médano-style paintings in Atacama Desert prehistory and Chilean archaeology (Mostny \& Niemeyer 1983, 1984; Niemeyer 2010). Niemeyer was apparently unaware that Capdeville had previously visited and recorded the paintings at (C) Antiquity Publications Ltd, 2018 


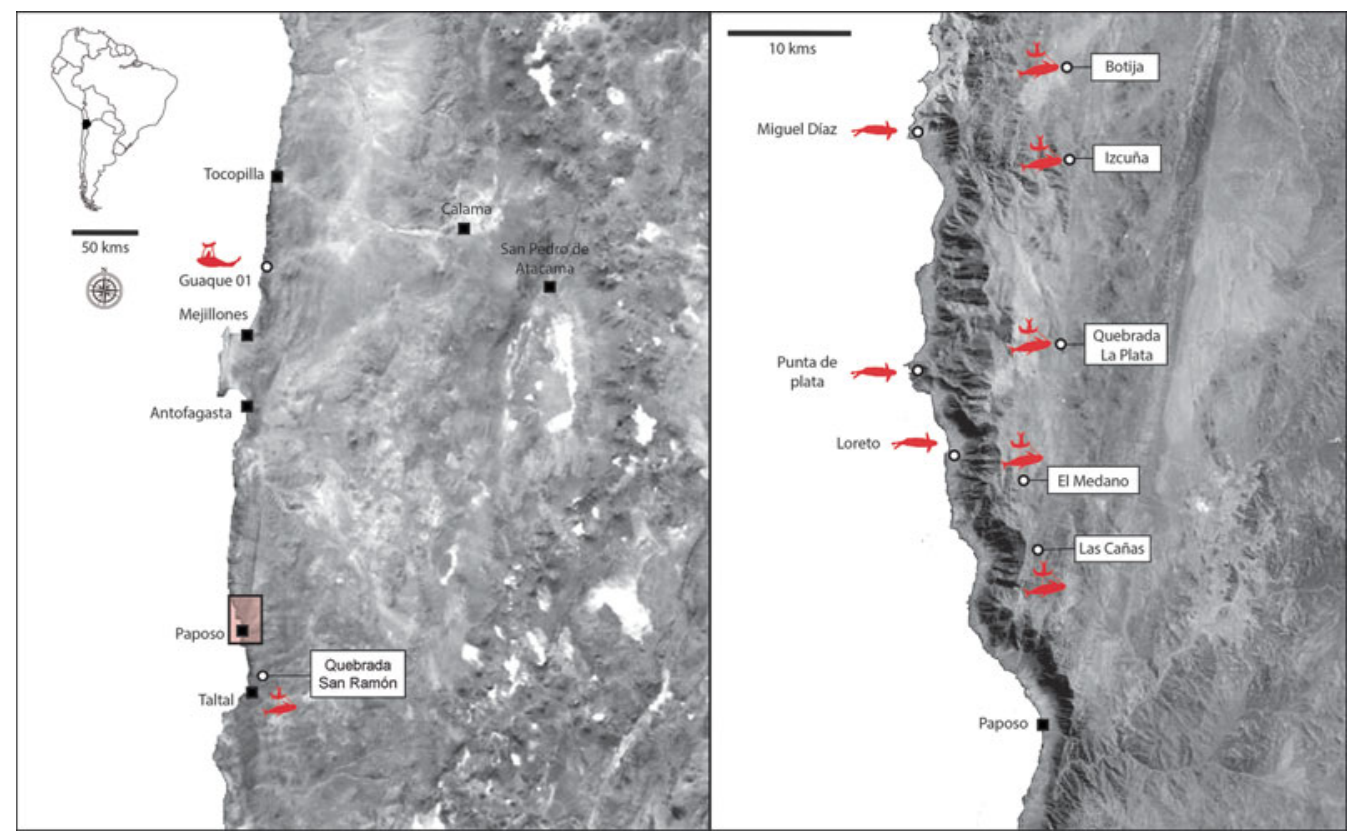

Figure 2. Location map from the different archaeological sites with El Médano paintings (icons marked in red). Single animal icons represent motifs without hunting scenes.

El Médano; traditional knowledge of their existence was confined to the native Paposo people.

Diverse research on the El Médano pictographs has since taken place (Berenguer 2009), encompassing interpretive, symbolic and archaeology of art approaches (the latter comparing local and coastal rock art to other styles in the Atacama Desert) (Núñez \& Contreras 2003, 2008; Contreras et al. 2008; Gallardo et al. 2012).

Nearly a century after Capdeville's recordings, we have discovered at least four new ravines with similar pictographs, located close to El Médano. Thus, our understanding of this rock art style, particularly of its geographic and spatial distribution (Figure 3), has completely changed. These new and important discoveries are presented here, with an emphasis placed on the Izcuña ravine pictographs to understand further their iconography, themes and composition.

\section{El Médano rock art temporality}

Establishing the chronology of a rock art style is always challenging (Bednarik 2002). Following the rediscovery of El Médano, Mostny and Niemeyer (1983, 1984) placed it relatively late in the littoral sequence-probably after $1000 \mathrm{BP}$, or in the Late Intermediate Period (1000-500 BP). Berenguer (2009) proposed a similar date based on characteristic headdresses in seafarer motifs-attire used principally in late pre-Hispanic times. Gallardo et al. (2012) argue that the 'dragging' depicted in El Médano hunting scenes is reminiscent of early pastoral paintings from the inland Atacama Desert, thereby supporting a relatively later date for the scenes. 

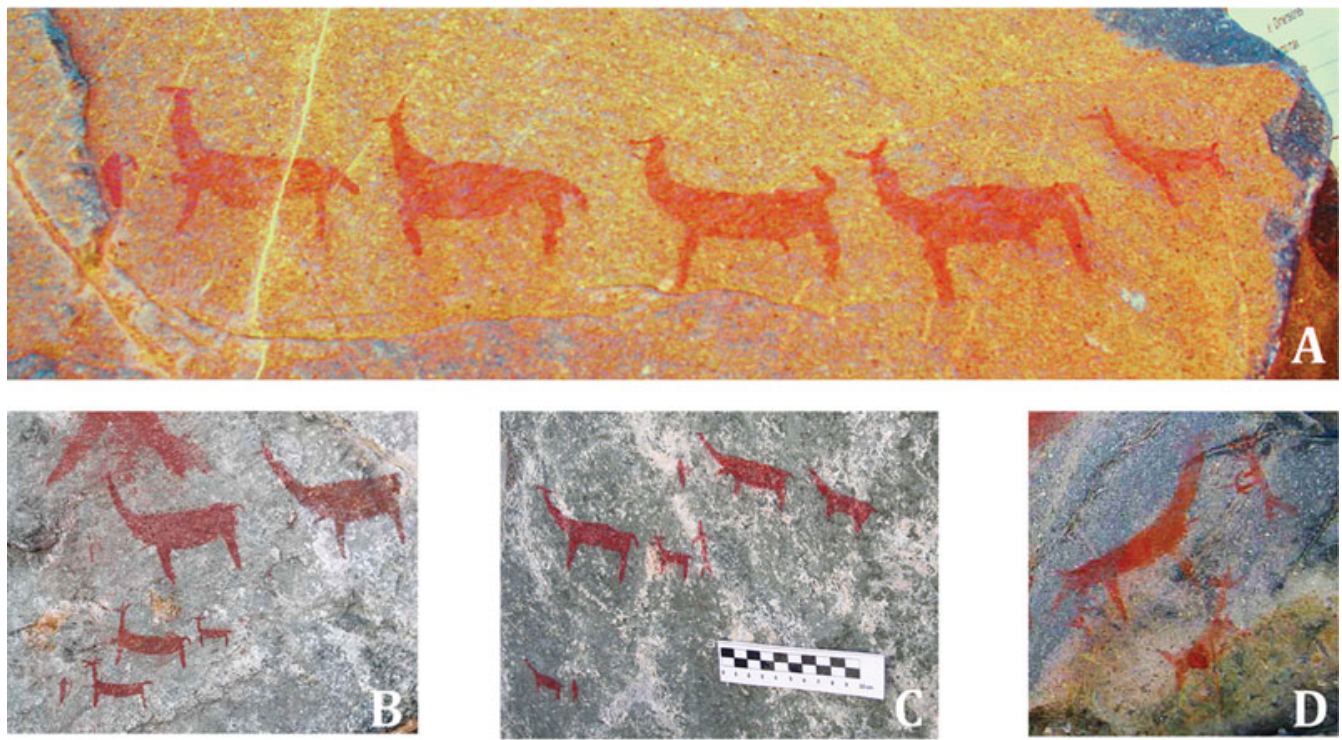

Figure 3. Camelid hunting scenes from El Médano: A) male camelids in a line formation, the first of them with an arrow in the chest and facing an anthropomorphic motif carrying a bow; B) anthropomorphic motif carrying an elongated bow alongside three camelids, two of them with arrows in the chest; $C$ ) three hunting scenes, one with an anthropomorphic motif holding $a$ bow and the camelid with an arrow in the chest (A-C photographed by Francisco Gallardo); D) figure with headdress carrying a bow facing two camelids, one of them with an arrow in the chest (Niemeyer 2010: 30-31).

A recent AMS date of an El Médano painting at the Punta de Plata shelter in Paposo has stimulated renewed discussion (Castelleti et al. 2015). Analysis dated the painting to $7882 \pm 160$ BP (Castelleti et al. 2015) — several millennia earlier than previously thought. This date, however, is inconsistent with both the occupational evidence at the site (dated to $1100 \mathrm{cal} \mathrm{BP}$ ) and with local prehistoric iconography. This inconsistency probably results from sample contamination (Ballester 2016). Capdeville (1918) recorded a small number of motifs depicting terrestrial (particularly camelid) hunting scenes, including anthropomorphic figures with bows and arrows. Some of these scenes also depict animals with arrows piercing their chests (Figure 3). Archaeological evidence suggests that this technology was developed in the Atacama Desert during the Formative Period (c. 3000 BP) and became popular in coastal areas around 1500 cal BP (Mostny 1964; de Souza 2004; Castelleti 2007). This provides some of the strongest evidence for a later date for this rock art style.

Furthermore, a few exceptional miniature figurines were discovered that model a similar style to El Médano rock art. Capdeville (1918) recorded some of these Late Intermediate Period finds recovered from the Caleta Cifunchos and Agua Dulce Cemeteries (Figure 4AB) (Mostny 1964; Fuenzalida \& Gallardo 2013). Ricardo Latcham (1910) recorded other specimens excavated near Antofagasta (Figure 4C). The most significant figurines, however, are surely those from the Lodwig Collection of Caldera, deposited in the Valparaiso Natural History Museum (Latorre et al. 2007). Recovered from Late Intermediate Period cemeteries, three of these are carefully modelled from laminated copper and closely resemble some of

(C) Antiquity Publications Ltd, 2018 


\section{El Médano rock art style}
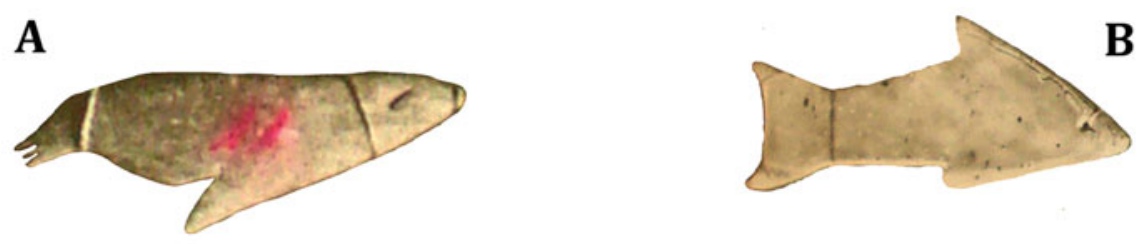

C
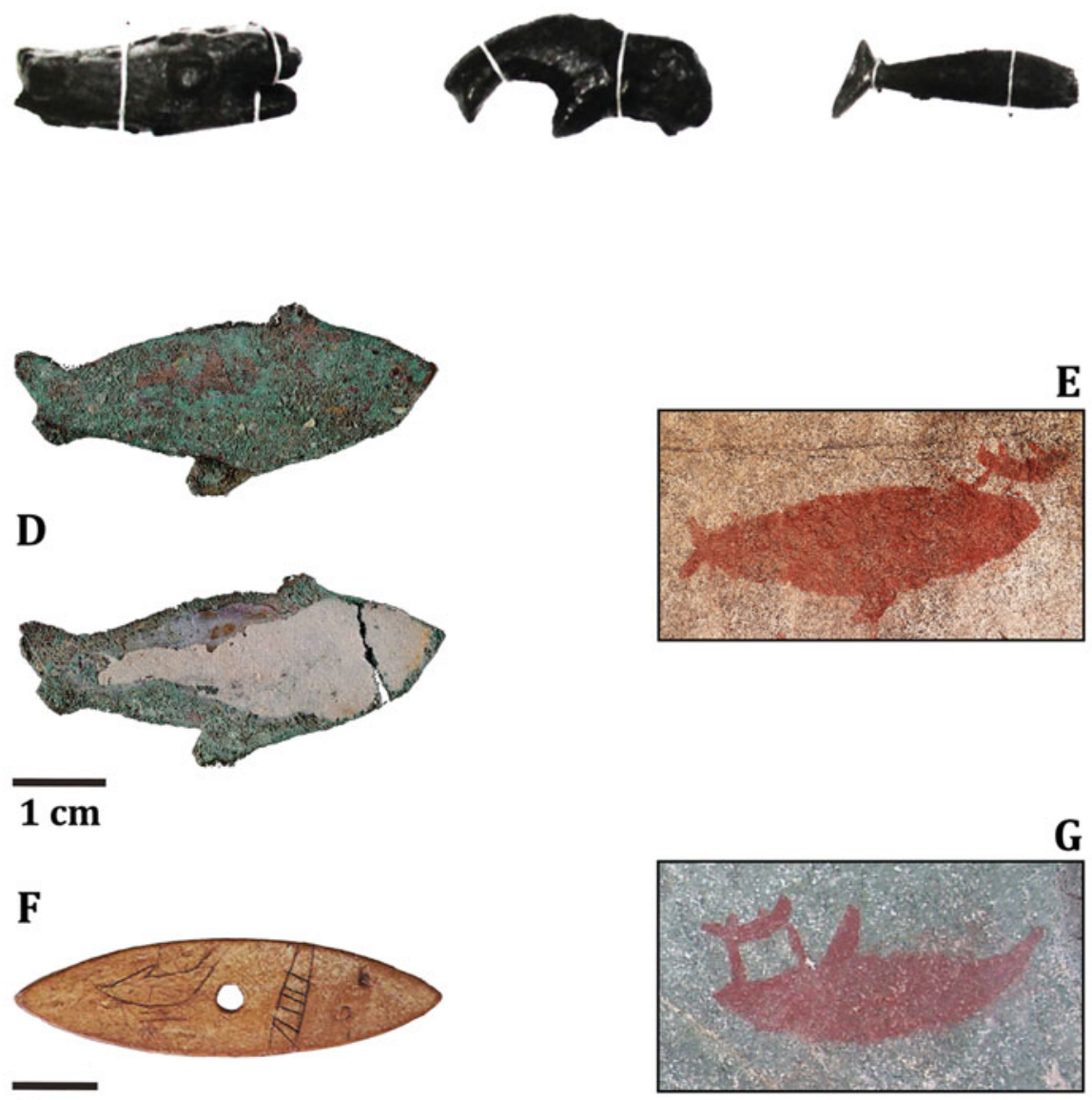

\section{$1 \mathrm{~cm}$}

Figure 4. Modelled miniature figurines: A-B) Cifuncho Cemetery, Taltal (Ballester 2016: fig. 3); C) Otto Aichel figures from Antofagasta; D) copper pieces from the Lodwig Collection (Latorre et al. 2007: Lám. 3); E) hunting scene painting from the Izcuña site (I-O2, block 08, panel 01); F) engraved spindle whorl from the Lodwig Collection; G) marine hunting scene from El Médano (photography by Francisco Gallardo). 


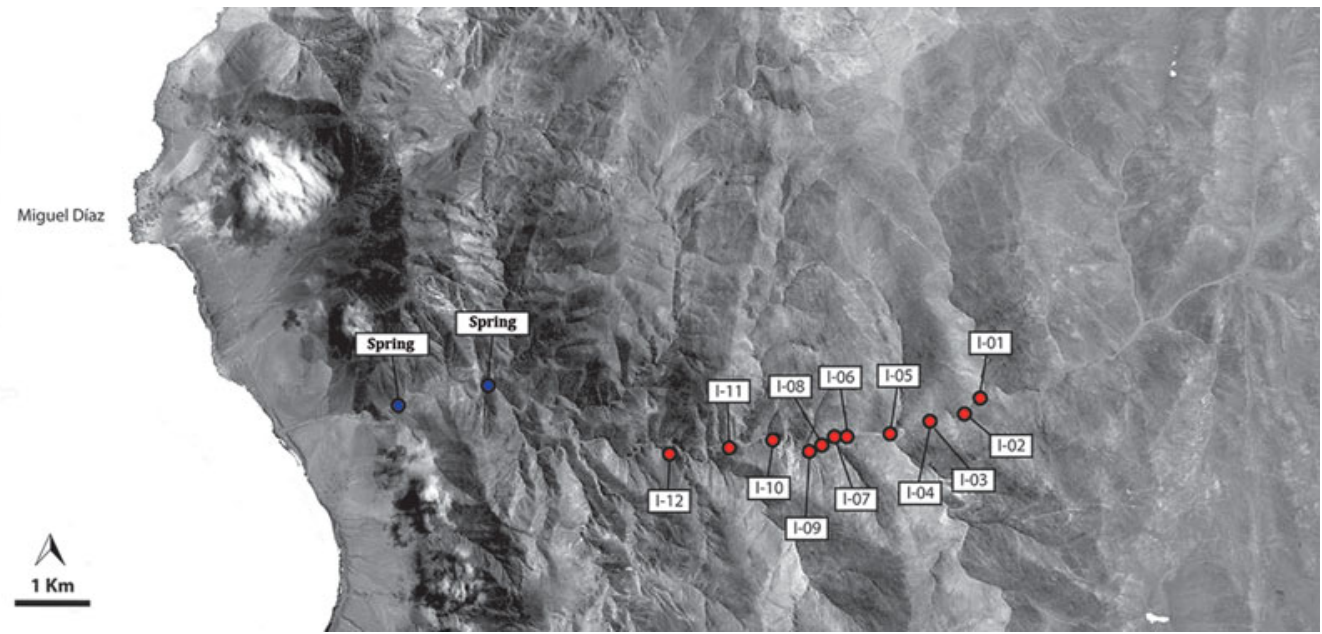

Figure 5. Location map of the different painting concentrations areas at Izcuña.

the rock art paintings (Figure 4D-E). Additionally, one of the spindle whorls from the collection is finely engraved with a pisciform that resembles some of the marine animals from El Médano (Figure 4F-G).

The archaeological provenance of these figurines supports the later date for El Médano rock art, and they bear the same style as portable objects that were offered to the deceased in Late Intermediate Period cemeteries. Metallurgic technology was also not present on the Atacama Desert coast before $2500 \mathrm{cal} \mathrm{BP}$, and only became popular in the Late Intermediate Period (Salazar et al. 2010). Conversely, spindle whorls are characteristic of this same period, especially the biconvex type common in the southernmost part of the Atacama Desert. Archaeological data have yet to provide concrete dates for El Médano rock art. For example, the AMS date of $7882 \pm 160 \mathrm{BP}$ contradicts the archaeological and iconographic evidence for the Late Formative or Late Intermediate Periods (Ballester 2016). Further research is necessary to address this problem of rock art chronology.

\section{Izcuña paintings}

Twelve discrete areas containing concentrations of paintings were identified in the Izcuña ravine, situated between 1320 and $680 \mathrm{~m}$ asl and in a $4.9 \mathrm{~km}$ linear sector (Figure 5). No other archaeological sites were documented in this area. In total, we recorded 24 blocks, 74 panels and 328 motifs (Table 1). All of these were painted in red colour, although with tonal variations from orange to deep red. The rock art distribution along the ravine is variable. The largest concentrations of paintings are in I-02 (67.7 per cent) and I-09 (16.8 per cent). $\mathrm{I}-02$ is located in a widening section of the ravine that is characterised by several shelters and exposed rock panels surrounding a central open space; the location is reminiscent of a natural amphitheatre.

All panels face into the ravine and are clearly visible to anyone within. Most of the paintings are very poorly preserved, having been heavily eroded by the camanchaca. Nevertheless, sufficient detail remains to facilitate morphological and stylistic analyses.

(C) Antiquity Publications Ltd, 2018 
Table 1. Izcuña rock art motif quantification.

\begin{tabular}{lccccc}
\hline & & & \multicolumn{3}{c}{ Motif } \\
\cline { 4 - 6 } Concentration & Block no. & Panel no. & Simple & Complex & Not identified \\
\hline I-01 & 1 & 1 & 6 & - & - \\
I-02 & 9 & 47 & 191 & 27 & 4 \\
I-03 & 1 & 1 & 2 & - & - \\
I-04 & 1 & 1 & - & - & 5 \\
I-05 & 1 & 2 & 5 & - & - \\
I-06 & 2 & 3 & - & 2 & - \\
I-07 & 1 & 1 & - & 2 & - \\
I-08 & 1 & 9 & 42 & 1 & - \\
I-09 & 3 & 2 & 2 & - & - \\
I-10 & 1 & 2 & 1 & 1 & - \\
I-11 & 1 & 3 & 14 & 2 & - \\
I-12 & 2 & & & & - \\
\hline
\end{tabular}

Within the Izcuña assemblage, simple motifs dominate over complex types (Table 1). In the former category, 50.3 per cent were drowned with filled technique (in which an image silhouette is filled with colour), while 45.4 per cent used the linear technique. Complex motifs, however, generally combined both techniques, especially in the marine hunting scenes where the raft and harpoon ropes are linear and prey is represented with solid colours (Figure 1). The most common motif is of pisciform animals, followed by hunting scenes, rafts and abstract subjects (Figure 6). While terrestrial animals appear in significant numbers, anthropomorphic representations are almost absent, except in the marine hunting scenes. Here, they are always depicted in a specific action and associated with rafts and prey. Hence, humans are under-represented as painting subjects, while the social action of hunting is strongly represented, using humans as just a part of the composition.

Hunting scenes are always represented in the same perspective: from the outside, giving a complete view of the act and never showing in first or principal plane the harpooning event. Rafts and prey are presented in a single visual plane, generally giving a natural perspective of the action, but without depicting the ocean itself. Although marine scenes (either of hunting from the surface or of the underwater animals) are the central theme of the rock art, the ocean itself is never explicitly represented. In simple pisciform motifs, the animals are most often painted in profile, while the other characters are represented in dorsal view (Table 2). Complex motifs, especially the hunting scenes, present a similar perspective ratio (71.74 per cent profile, 28.26 per cent dorsal) (Figure 7). In contrast, rafts are always represented from the same perspective and following a standardised norm: an inverted half-moon form, such as a concave motif with the seafarers in the interior. Different perspectives depicting animals probably result from constant real-life sightings of animals from multiple angles. A vast corpus of anatomical and behavioural imagery is therefore created.

In hunting scenes, prey is always represented as oversized (averaging 3.9 times bigger) compared to rafts and their crew (Figure 8). This style intentionally places the prey as the protagonist, as evidenced by the detailed, meticulous depictions of the anatomy and 


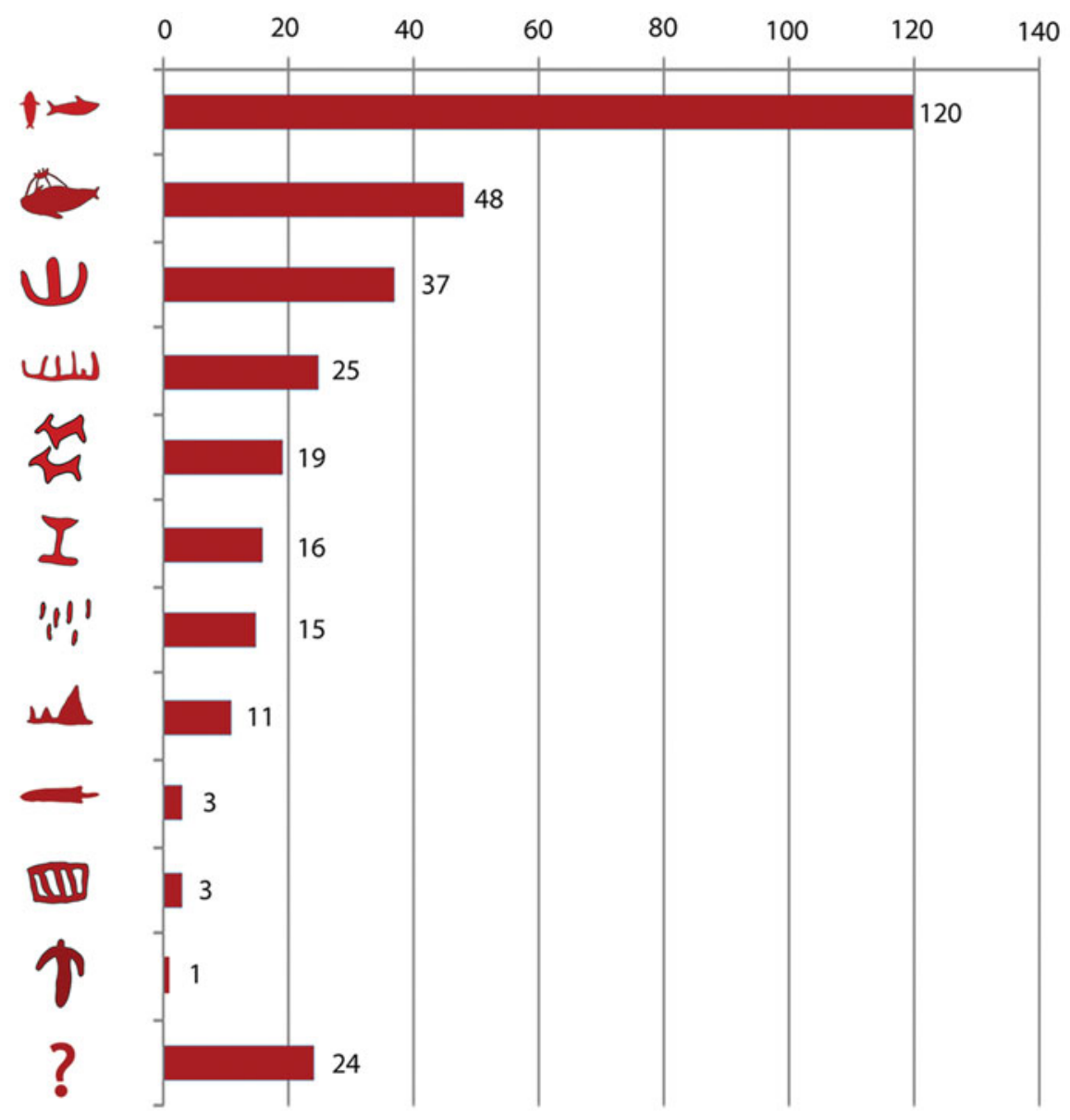

Figure 6. Quantitative chart of the proportions of different simple and complex motifs identified at Izcuña.

physiology of the animals. This is contrasted by the simple, undetailed human drawings created using lineal strokes (Figure 7). Detail here is limited to the occasional seafarer's headdress, represented by two lateral protuberances (Table 2).

A particular aspect of the animal representations is important. In simple pisciform motifs, marine animals are always painted in their natural position, with the dorsal side facing upwards and the ventral side facing downwards. In hunting scenes, however, a significant percentage of prey animals are painted inverted, with the ventral side up and dorsal side down (Figure 7A). This graphical inversion is probably related to their natural rotation process during sea hunting. Practically all hunting scenes depict a single raft hunting a single animal, except for a unique motif of two rafts trapping a single animal (Table 2). This opposes the previously observed classic El Médano style, which more commonly depicts other configurations (Mostny \& Niemeyer 1983, 1984). Regardless, the hunting activity is represented as a single practice, mainly conducted by one raft. In most cases they exhibit only one seafarer inside the boat (Table 2). Overall, hunting is represented as a specialised, (C) Antiquity Publications Ltd, 2018 

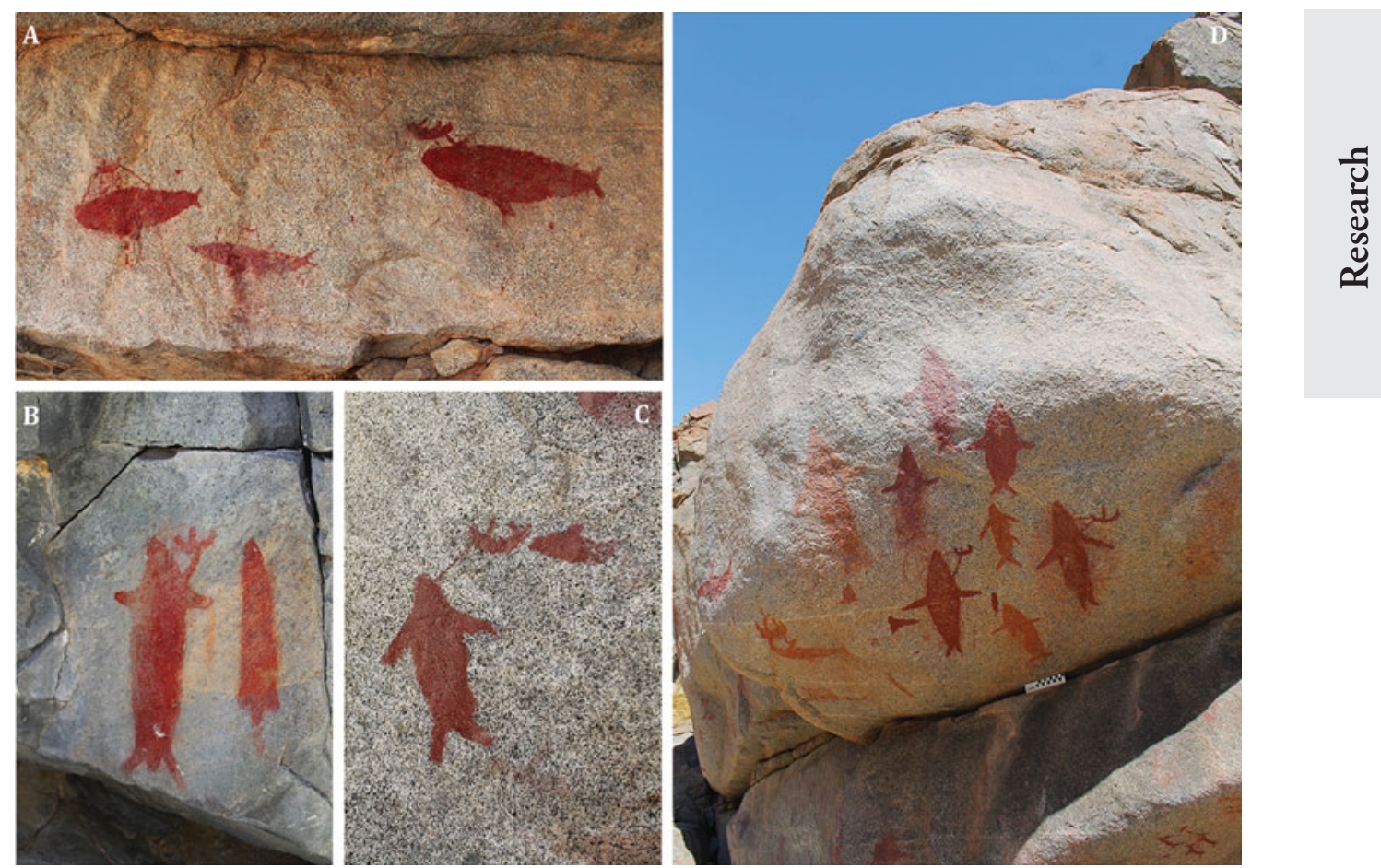

Figure 7. Izcuña hunting scenes: A) I-02, block 08, panel 01; B) I-11, block 01, panel 01; C) I-09, block 09, panel 01; D) I-02, block 09, panel 08.

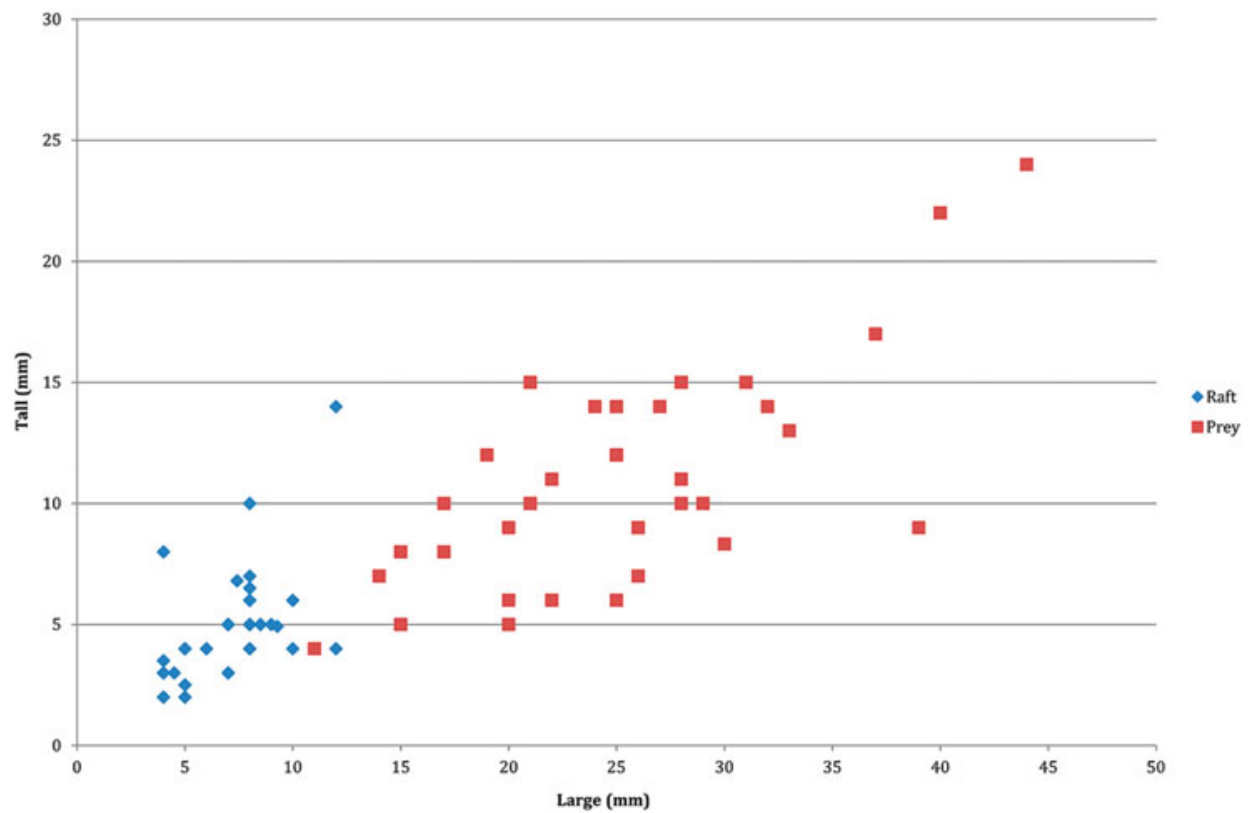

Figure 8. Size comparison between rafts and prey animals from the Izcuña hunting scenes.

(C) Antiquity Publications Ltd, 2018 
Table 2. Izcuña iconographic elements.

\begin{tabular}{|c|c|c|c|c|c|c|}
\hline & $\begin{array}{l}\text { Number } \\
\text { of rafts }\end{array}$ & $\begin{array}{l}\text { Number of } \\
\text { seafarers }\end{array}$ & Headdress & $\begin{array}{c}\text { Number of } \\
\text { hunting lines }\end{array}$ & $\begin{array}{l}\text { Harpooning } \\
\text { place }\end{array}$ & Perspective \\
\hline Total Sample & 48 & 48 & 48 & 48 & 75 & 48 \\
\hline$\overline{1}$ & $97.92 \%$ & - & - & - & - & - \\
\hline 2 & $2.08 \%$ & - & - & - & - & - \\
\hline 1 & - & $47.92 \%$ & - & - & - & - \\
\hline 2 & - & $35.42 \%$ & - & - & - & - \\
\hline No & - & $14.58 \%$ & - & - & - & - \\
\hline Indet. & - & $2.08 \%$ & - & - & - & - \\
\hline $\begin{array}{l}\text { Seafarer with } \\
\text { headdress }\end{array}$ & - & - & $12.50 \%$ & - & - & - \\
\hline $\begin{array}{l}\text { Seafarer without } \\
\text { headdress }\end{array}$ & - & - & $79.17 \%$ & - & - & - \\
\hline $\begin{array}{l}\text { Presence of } \\
\text { headdress } \\
\text { indet. }\end{array}$ & - & - & $8.33 \%$ & - & - & - \\
\hline 1 & - & - & - & $41.62 \%$ & - & - \\
\hline 2 & - & - & - & $30.95 \%$ & - & - \\
\hline 3 & - & - & - & $19.05 \%$ & - & - \\
\hline 4 & - & - & - & $2.32 \%$ & - & - \\
\hline Indet. & - & - & - & $6.06 \%$ & - & - \\
\hline Head & - & - & - & - & 37 & - \\
\hline Fin & - & - & - & - & 18 & - \\
\hline Medial & - & - & - & - & 15 & - \\
\hline Tail & - & - & - & - & 5 & - \\
\hline Profile & - & - & - & - & - & $68.75 \%$ \\
\hline Plate & - & - & - & - & - & $27.08 \%$ \\
\hline Indet. & - & - & - & - & - & $4.17 \%$ \\
\hline
\end{tabular}

solitary, individual social practice, led by a selected few people. As previously mentioned, in hunting scenes, rafts and prey are connected by lines that represent harpoon ropes. The quantity of lines varies from scene to scene, increasing in frequency from one line (most frequently depicted), to two, three and four lines (least frequently depicted) (Table 2). The line most commonly connects to the prey's head, pectoral fin, medial part of the body and, least frequently, the tail (Table 2). The depiction of multiple harpoon lines attached to a single animal offers a graphic expression of intense and complex open-ocean hunting expeditions.

\section{From red paintings to ocean hunting}

Social representations are, by necessity, linked to reality. They may be transformed, inverted, distorted or modified, but they are always linked to real events. El Médano rock art was created by marine hunter-gatherers with a long historical tradition in the coastal desert (C) Antiquity Publications Ltd, 2018 


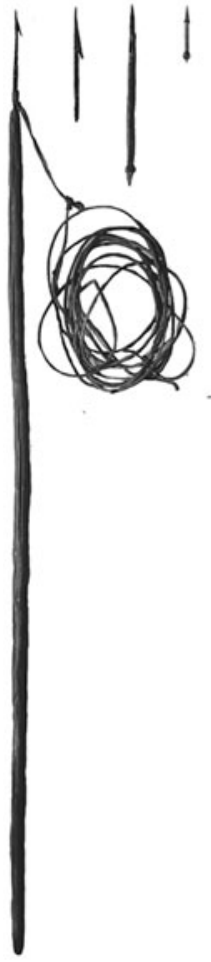

A

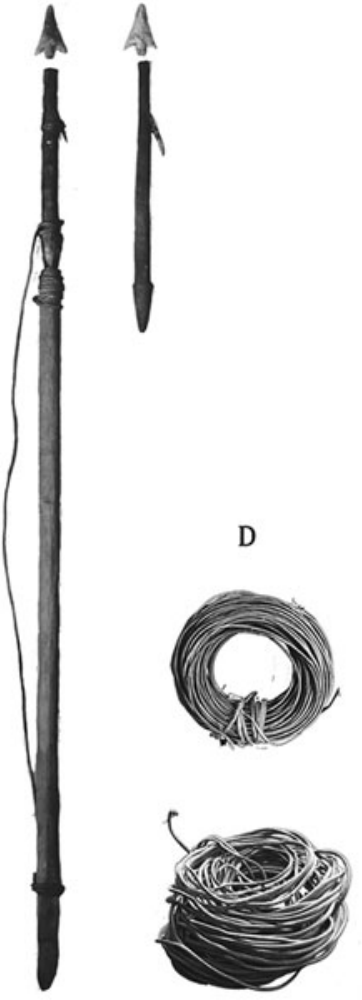

B

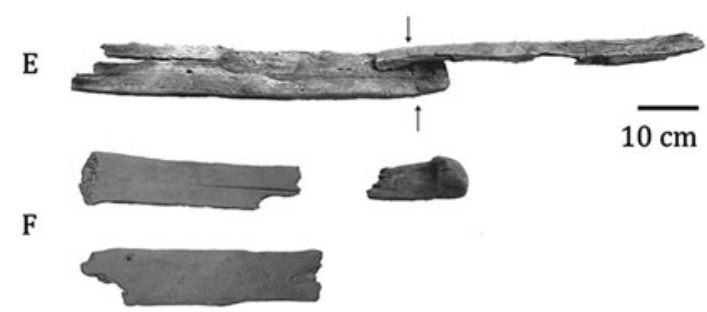

\section{G}

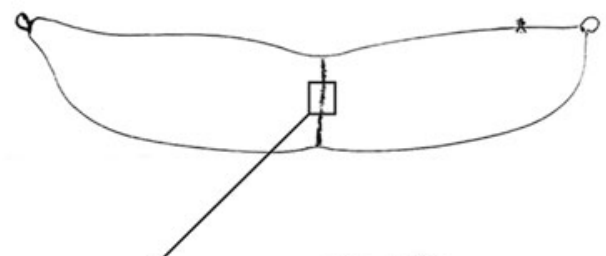

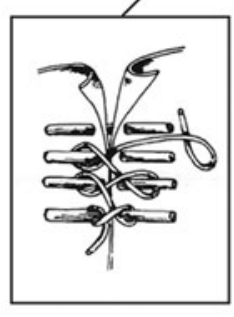

$\mathrm{H}$

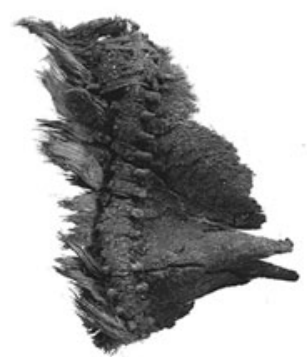

I $\quad \overline{2 \mathrm{~cm}}$

Figure 9. Archaeological remains related to hunting activities: A-B) complete harpoon (Bird 1946: pl. 123a-j); C-D) rolled harpoon lines from the Camarones 9 site; E) composite oar fragment from the Guaque 07 site-arrows indicate billet position; F) oar fragments from AutoClub de Antofagasta Cemetery; G) float outline from a raft made of sea lion skin (Niemeyer 1965-1966); H) detail of the cactus spine and cotton zig-zag seam (Niemeyer 1965-1966); I) float fragment with spine seam from a raft made of sea lion skin and recovered from El Trocadero Cemetery, Antofagasta.

(True 1975; Llagostera 1989; Núnez 1999; Salazar et al. 2015). Archaeological analysis of faunal assemblages from residential middens, dating from $7000 \mathrm{cal} \mathrm{BP}$ to the sixteenthcentury European arrival, demonstrates the capture, butchering and consumption of large marine prey species, such as swordfish, sharks, marlin, tuna, dolphins, sea lions and some whale species. This attests to an extended and important cultural and economic tradition of marine hunting (Mostny 1942; Bird 1943; Núñez et al. 1974; Contreras et al. 2011; Castro et al. 2012; Olguín et al. 2014, 2015; Rebolledo et al. 2015; Béarez et al. 2016). Archaeological evidence for harpoons is abundant but poorly studied (Llagostera 1989). Harpoons were composite devices comprising a wooden shaft of up to $3 \mathrm{~m}$ in length, a detachable head and a single line of up to $70 \mathrm{~m}$ in length, made of sea lion skin (Figure 9AD) (Ballester in press). Harpoon heads are also composite, with parts made from different raw materials, including wood stems, cactus spine barbs, lithic points, copper barbs, cotton strings, bone barbs, vegetal resins and pigment coating (Ballester in press). Harpoons are 
present in middens dating to $7000 \mathrm{cal} \mathrm{BP}$, only becoming popular as funerary offerings after $6000-5000 \mathrm{cal} \mathrm{BP}$.

The raft employed in pre-Hispanic times was similar to those described centuries later by Europeans (Figure 10). Such rafts comprised two large cylindrical floating sections made of sea lion skin, which when tied together

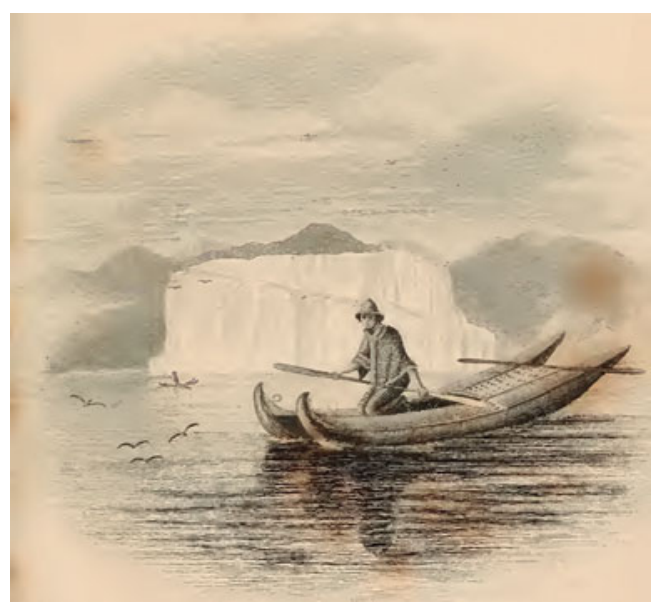

Figure 10. Fisherman sailing in a raft made of sea lion skin on the Atacama Desert coast between 1820 and 1822 (photograph from Hall 1827). measured almost $3 \mathrm{~m}$ in length (Figure 9G). The floating sections were carefully sewn together using hundreds of cactus spines and cotton thread in a zig-zag pattern (Figure 9H-I). Finally, the floating sections were completely sealed and water proofed with a red ochre substance (Frezier 1717; Lesson 1838; Niemeyer 1965-1966; Bibar 1966 [1558]). Archaeological evidence for these rafts is rare but does exist. Oar fragments, for example, have been identified in different Late Intermediate Period cemeteries from Caleta Huelen at the Loa River Mouth, Mejillones, Antofagasta and Taltal (Bittmann 1978; Núñez 1986). One fragment recovered from the Guaque 07 Cemetery was directly dated to 545-499 cal BP at $100 \%$ (wood,

Beta-334311, SHCal13 curve (Stuiver et al. 2005; Hogg et al. 2013)). This was a particularly interesting artefact due to its sophisticated manufacturing technology. It was a composite of two different types of wood - cactus for the palette and hardwood for the pole. These were attached together using a bevel system and with thick cactus spines serving as billets (Figure 9E). Similar oars have been recovered from the AutoClub Cemetery located in Antofagasta city (Figure 9F), dated directly to $819-724$ cal BP at $84 \%$ (wood, Beta335821, SHCal13 curve (Stuiver et al. 2005; Hogg et al. 2013; Ballester et al. 2014)).

Ethnohistorical and historical sources describe marine hunting using traditional inflated rafts of sea lion skin and harpoon devices. The most famous reference is from Antonio Vásquez de Espinoza's book (1948 [1630]), which illustrated a dangerous and complicated whale-hunting scene carried out by only one hunter. Reginaldo de Lizárraga (1999 [16031609]: 378) correspondingly recorded the hunting of tuna,

not in crews like in Spain, but as a lone Indian fisherman going out in a sea lion skin raft, two or three leagues from the coast; carrying his harpoon, attacking, giving rope until the prey bleeds to death, then dragging it to the coast [author's translation].

It is in this context that analysis of the Izcuña rock art acquires value and relevance. As previously discussed, pictorial representations of marine hunting have depicted it as an individual, rather than collective, practice — often with rafts operated by a single occupant. The boats are similar in form to those made of inflated sea lion skin, especially in their raised ends. Yet rock art pictographs give us information beyond that available in the (C) Antiquity Publications Ltd, 2018 
archaeological record. Marine hunting was not only nutritive (evidenced by archaeological animal bone) or technological (evidenced by fragments of harpoons), but also symbolic and ideological. The rock art offers clues concerning hunting strategies, such as labour organisation, hunting roles, the number of harpoon lines involved in the hunt, animal movement during the chase, the position of attack and the perspectives of painters. They also contain a huge corpus of information concerning the cultural knowledge of animal anatomy, physiology and behaviour-essentially, their interspecies relationships. For unknown reasons, the pictographs usually represent successfully accomplished hunting scenes, once the animal is harpooned. Thus, they most often represent success in the hunt, rather than the process of hunting.

The artistic expression of this body of ancestral and complex knowledge occurs only in specific places. Although the pictographs are evident in a few rockshelters near the shore, they occur far more frequently in ravines several kilometres from the ocean. These are often at over $700 \mathrm{~m}$ asl, in ravines that are narrow and difficult to access. The painters portrayed a marine activity in a desert setting, in a conscious act of linking the ocean to the desert via rock art. But they were also linked by technology, as the harpoons and rafts comprised materials obtained from the inland desert, such as lithics, red ochre, wood, cotton, resin, cactus, and camelid bone. Hence, both economic and representational spheres were linked by the same conception of landscape that bound together the sea and the desert. For the hunter-gatherers of the Atacama Desert coast, this represents two aspects of a single process in the social construction of their territory and culture.

\section{Acknowledgements}

Funding for this research was provided by FONDECYT (1160045 \& 1140056) and FONDAP (15110006). Thanks go to Javier Álvarez, Francisco Gallardo (El Médano photography), Daniel Quiroz, Carolina Carrasco and Marcela Sepúlveda. Special thanks go to Museo San Miguel de Azapa de la Universidad de Tarapacá, the Museo de Antofagasta and to the National Service of Geology and Mining.

\section{References}

Ballester, B. 2016. El tiempo de El Médano. Taltalia 9: 49-62.

- In press. Tecnología de arponaje en la costa del desierto de Atacama, norte de Chile. Estudios Atacameños.

Ballester, B. \& A. Clarot. 2014. La gente de los túmulos de tierra. Santiago: Marmot Impresores.

Ballester, B. \& F. Gallardo. 2011. Prehistoric and historic networks on the Atacama Desert coast (northern Chile). Antiquity 85: 875-89.

- 2016. Painting a lost world. The red rock art of El Médano. Current World Archaeology 77: 36-38.

Ballester, B., A. Clarot \& A. Llagostera. 2014. El Cementerio de Auto Club de Antofagasta y la sociedad litoral entre los 1000 y 1450 d.C. Hombre y Desierto 18: 187-212.
Ballester, B., F. Gallardo \& P. Aguilera. 2015. Representaciones que navegan más allá de sus aguas: una pintura estilo El Médano a más de $250 \mathrm{~km}$ de su sitio homónimo. Boletín de la Sociedad Chilena de Arqueología 45: 81-94.

Béarez, P., F. Fuentes-Mucherl, S. Rebolledo, D. Salazar \& L. Olguín. 2016. Billfish foraging along the northern coast of Chile during the Middle Holocene (7400-5900 cal BP). Journal of Anthropological Archaeology 41: 185-95. https://doi.org/10.1016/j.jaa.2016.01.002

BEDNARIK, R. 2002. The dating of rock art: a critique. Journal of Archaeological Science 29: 1213-33. https://doi.org/10.1006/jasc.2001.0711

Berenguer, J. 2009. Las pinturas de El Médano, norte de Chile: 25 años después de Mostny y Niemeyer. Boletín del Museo Chileno de Arte Precolombino 14(2): 57-95. https://doi.org/10.4067/S071868942009000200004 
Bibar, G. 1966 [1558]. Crónica y relación copiosa y verdadera de los Reynos de Chile. Santiago: Fondo Histórico y Bibliográfico José Toribio Medina.

BIRD, J. 1943. Excavations in northern Chile. Anthropological Papers of the American Museum of Natural History 38: 173-318.

- 1946. The cultural sequence of the north Chilean coast. Bulletin of the Bureau of American Ethnology 143: 587-94.

Bittmann, B. 1978. Fishermen, mummies and balsa rafts on the coast of northern Chile. El Dorado 3(3): 60-103.

Bland, R. 2010. Another look at the Pegtymel' petroglyphs. Arctic Anthropology 47(2): 22-31. https://doi.org/10.1353/arc.2010.0014

Burningham, N. 1994. Aboriginal nautical art: a record of the Macassans and the pearling industry in northern Australia. The Great Circle 16: 139-51.

Capdeville, A. 1918. Arqueología. Llanura del Hueso Parado. Cementerio de los túmulos de tierra. Unpublished field notes, held at the Augusto Capdeville Rojas Museum of Taltal.

Castelleti, J. 2007. Patrón de asentamiento y uso de recursos a través de la secuencia ocupacional prehispánica en la costa de Taltal. Unpublished MA dissertation, Universidad Católica del Norte.

Castelleti, J., A. Goguitchaichvili, C. Solís, M. Rodríguez \& J. Morales. 2015. Evidencia de tempranas manifestaciones rupestres en la costa del desierto de Atacama ( $\left.25^{\circ} \mathrm{S}\right)$. Arqueología Iberoamericana 28: 16-21.

Castro, V., C. Aldunate \& V. Varela. 2012. Paisajes culturales de Cobija, Costa de Antofagasta, Chile. Revista Chilena de Antropología 26(2): 97-128.

Conti, K., W. Hyder \& A. Padgett. 1999. Cave of the Whales: rock art on San Nicolas Island, in D. Browne, K. Mitchell \& H. Chaney (ed.) Proceedings of the Fifth California Islands Symposium: 669-76. Camarillo (CA): U.S. Department of the Interior Minerals Management Service, Pacific OCS Region.

Contreras, R., P. NúÑez \& O. Rodríguez. 2008. El Médano: reflexiones antropológicas en torno a la cosmovisión de los habitantes prehispánicos de la costa sur del Norte Grande. Taltalia 1: 87-122.

Contreras, R., P. Núñez, A. Llagostera, J. Cruz, A. San Francisco, B. Ballester, O. Rodriguez \& G. Becerra. 2011. Un conglomerado del período Arcaico costero Medio del área Taltal Paposo, norte de Chile. Taltalia 4: 7-31.

Dikov, N. 1971. Mysteries in the rock of ancient Chukotka (Pethroplyphs of Pegtymel). Translated by Richard L. Bland. Moscow: Nauka.
Frezier, M. 1717. Relation du voyage de la mer du sud aux cotes du Chili, du Perou, et du Bresil, fait pendant les années 1712, 1713 \& 1714. Amsterdam: Pierre Humbert.

Fuenzalida, N. \& F. Gallardo. 2013. Exchange and ritual funerary consumption: late marine hunter-gatherers of the Taltal Coast (Atacama Desert, northern Chile). Andean Past 11: 263-81.

Gallardo, F., G. Cabello, G. Pimentel, M. Sepúlveda \& L. Cornejo. 2012. Flujos de información visual, interacción social y pinturas rupestres en el desierto de Atacama (norte de Chile). Estudios Atacameños 43: 35-52. https://doi.org/10.4067/S071810432012000100003

HaLl, B. 1827. Extracts from a journal, written on the coasts of Chili, Peru, and Mexico, in the years 1820, 1821, 1822. Edinburgh: Printed for Archibald Constable and Co.

Hogg, A.G., Q. Hua, P.G. Blackwell, M. Niu, C.E. Buck, T.P. Guilderson, T.J. Heaton, J.G. Palmer, P.J. Reimer, R.W. Reimer, C.S.M. Turney \& S.R.H. Zimmerman. 2013. SHCal13 southern hemisphere calibration, 0-50,000 years cal BP. Radiocarbon 55: 1889-1903. https://doi.org/10.2458/azu_js_rc.55.16783

Hudson, T. \& K. Contr. 1981. The 'aquatic motif in Chumash rock art. Journal of California and Great Basin Anthropology 3: 224-31.

JeON, H. \& J. Kiм. 2013. Bangudae: petroglyph panels in Ulsan, Korea, in the context of world rock art. Seoul: Hollym.

Latcham, R. 1910. Los changos de las costas de Chile. Santiago: Imprenta Cervantes.

Latorre, E., M. Plaza \& R. Riveros. 2007. El caso de la Colección Lodwig: caracterización d'un conjunto de piezas metálicas prehispánicas del litoral de Caldera (III Región, Chile). Werkén 11: 89-105.

LeE, S. \& D. Robineau. 2004. Les cétacés des gravures rupestres néolithiques de Bangu-dae (Corée du Sud) et les débuts de la chasse à la baleine dans le Pacifique nord-ouest. L'Anthropologie 108: 137-51. https://doi.org/10.1016/j.anthro.2004.01.001

LESSON, R. 1838. Voyage autor du monde, enterpris par ordre du gouvernement sur La Corvette La Coquille. Paris: Pourrat Freres.

DE Lizárraga, R. 1999 [1603-1609]. Descripción del Perú, Tucumán, Río de la Plata y Chile. Buenos Aires: Union Académique Internationale, Academia Nacional de Historia.

Llagostera, A. 1979.9700 years of maritime subsistence on the Pacific: an analysis by means of bioindicators in the north of Chile. American Antiquity 44: 309-24. https://doi.org/10.2307/279082

(C) Antiquity Publications Ltd, 2018 
- 1989. Caza y pesca marítima, in J. Hidalgo, V. Schiappacasse, H. Niemeyer, C. Aldunate \& I. Solimano (ed.) Prehistoria. Desde sus orígenes hasta los albores de la conquista: 57-81. Santiago: Andrés Bello.

- 1992. Early adaptations and the emergence of fishermen on the Pacific Coast of South America. Andean Past 3: 87-109.

Lundy, D. 1974. The rock art of the northwest coast. Unpublished MA dissertation, Simon Fraser University.

McCarthy, F. 1961. The rock engravings of Depuch Island, north-west Australia. Records of the Australian Museum 25(8): 121-48. https://doi.org/10.3853/j.0067-1975.25.1961.660

Meighan, C. 2000. Rock art on the Channel Islands of California. Pacific Coast Archaeological Society Quarterly 36(2): 15-29.

Mostny, G. 1942. Informe preliminar sobre las excavaciones efectuadas en la costa chilena entre Pisagua y Coquimbo del 8 de octubre de 1941 al 15 de marzo de 1942. Boletín del Museo Nacional de Historia Natural 20: 97-102.

- 1964. Arqueología de Taltal: epistolario de Augusto Capdeville con Max Uhle y otros. Santiago: Fondo Histórico y Bibliográfico José Toribio Medina.

Mostny, G. \& H. Niemeyer. 1983. Arte rupestre chileno. Santiago: Ministerio de Educación, Departamento de Extensión Cultural.

- 1984. Arte rupestre en El Médano, II Región. Creces $9(5): 2-5$.

Niemeyer, H. 1965-1966. Una balsa de cueros de lobo de la caleta de Chañaral de Aceitunas (Prov. De Atacama, Chile). Revista Universitaria 50-51: 257-69.

- 2010. Crónica de un descubrimiento. Las pinturas rupestres de El Médano, Taltal. Santiago: Museo Chileno de Arte Precolombino.

NúÑEz, L. 1986. Balsas prehistóricas del litoral chileno: grupos, funciones y secuencia. Boletín del Museo Chileno de Arte Precolombino 1: 11-35.

- 1999. Archaic adaptation on the south-central Andean Coast, in M. Blake (ed.) Pacific Latin America in prehistory. The evolution of Archaic and Formative cultures: 199-211. Pullman: Washington State University Press.

NúŃEZ, L. \& J. VARELA. 1967-1968. Sobre los recursos de agua y el poblamiento prehispánico de la costa del Norte Grande de Chile. Estudios Arqueológicos 3-4: 7-41.

NúN̄ez, L., V. Zlatar \& P. NúÑEZ. 1974. Caleta Huelén 42; una aldea temprana en el norte de Chile (nota preliminar). Hombre y Cultura 2(5): 67-103.

Núñez, P. \& R. Contreras. 2003. Pinturas prehispánicas de Taltal. Antofagasta: Impresión Ercilla.
- 2008. El arte rupestre de Taltal norte de Chile. Taltalia 1: 77-85.

O'Connor, S. 2008. Boat images in the rock art of northern Australia with particular reference to the Kimberley, Western Australia, in G. Cark, F. Loss \& S. O'Connor (ed.) Islands of inquiry. Colonisation, seafaring and the archaeology of maritime landscapes: 397-409. Canberra: ANU E Press.

Olguín, L., D. Salazar \& D. Jackson. 2014. Tempranas evidencias de navegación y caza de especies oceánicas en la costa pacífica de Sudamérica (Taltal, 7.000 años cal. a.p.). Chungara, Revista de Antropología Chilena 46: 177-92. https://doi.org/10.4067/S071773562014000200002

Olguín, L., V. Castro, P. Castro, I. Peña-Villalobos, J. Ruz \& B. Santander. 2015. Exploitation of faunal resources by marine hunter-gatherer groups during the Middle Holocene at the Copaca 1 site, Atacama Desert coast. Quaternary International 373: 4-16. https://doi.org/10.1016/j.quaint.2015.02.004

PAskoff, R. 1978-1979. Sobre la evolución geomorfológica del grana acantilado costero del norte grande de Chile. Norte Grande 6: 7-22.

Rebolledo, S., P. Béarez, D. Salazar \& F. Fuentes. 2015. Maritime fishing during the Middle Holocene in the hyperarid coast of the Atacama Desert. Quaternary International 391: 3-11. https://doi.org/10.1016/j.quaint.2015.09.051

Salazar, D., V. Castro, J. Michelow, H. Salinas, V. Figueroa \& B. Mille. 2010. Minería y metalurgia en la costa arreica de la Región de Antofagasta, norte de Chile. Boletín del Museo Chileno de Arte Precolombino 15(1): 9-23. https://doi.org/10.4067/S071868942010000100002

Salazar, D., V. Figueroa, P. Andrade, H. Salinas, X. Power, S. Rebolledo, S. Parra, H. Orellana \& J. UrRea. 2015. Cronología y organización económica de las poblaciones arcaicas de la costa de Taltal. Estudios Atacameños 50: 7-46.

https://doi.org/10.4067/S071810432015000100002

DE SouzA, P. 2004. Tecnologías de proyectil durante los períodos Arcaico y Formativo en el Loa Superior (norte de Chile): a partir del análisis de puntas líticas. Chungara, Revista de Antropología Chilena 36 (special volume, issue 1): 61-76.

Specht, R. 2012. American-Australian scientific expedition to Arnhem Land (1948): its long-range impact. The Open Ecology Journal 5: 53-83. https://doi.org/10.2174/1874213001205010053

Stuiver, M., P. Reimer \& R. Reimer. 2005. CALIB 5.0. Available at: http://intcal.qub.ac.uk/calib/manual/index (accessed 14 August 2017). 
Torres, L., D. Gutiérrez, J. GonZÁlez,

R. Fernández \& Y.C. Tavárez. 2011. Reflexiones sobre el posible papel de las ballenas en los modos de vida precolombinos del caribe insular, República Dominicana, un caso de ejemplo. Anti 10: 14-24.

TRUE, D. 1975. Early maritime cultural orientations in prehistoric Chile, in R. Casteel \& G. Quimby (ed.) Maritime adaptations of the Pacific: 89-143. Paris: Mouton.
TuRner, D. 1973. The rock art of Bickerton Island in comparative perspective. Oceania 43: 286-325. https://doi.org/10.1002/j.18344461.1973.tb01225.x

VÁsquez de Espinoza, A. 1948 [1630]. Compendio y descripción de las indias occidentales. Washington, D.C.: Smithsonian Institution.

Received: 21 November 2016; Accepted: 21 February 2017; Revised: 24 February 2017

(C) Antiquity Publications Ltd, 2018 